\title{
Based on the DEA model of security housing construction efficiency research
}

\author{
Da Li, Qinjun Du
}

China Shijiazhuang city of Huai'an East Road No. 136, Shijiazhuang university of economics: Graduate school of management science and engineering,liidaa007@qq.com

China Shijiazhuang city of Huai'an East Road No. 136, Shijiazhuang university of economics: Graduate school of management science and engineering,13315111053@189.cn

\section{Keywords: Data Envelopment Analysis (DEA) Security Room Construction Efficiency}

\begin{abstract}
Social indemnificatory housing is in the construction of house of our country town with relatively particularity a type of housing, it is usually refers to according to the national policy and legal regulations, unified planning, by the government as a whole, to provide specific people use, and on this kind of housing construction standards and sales price or rent standard to limit, the social security function of housing. The paper USES data envelope analysis method, in order to hebei province various administrative city in January 2012 to August safeguard room construction progress data as the research object, analyses the related statistics and analysis, compare the city in hebei province administrative safeguard room construction progress, obtain the progress development not balanced result, among them, the individual administrative city obviously lag behind other locally administratered level. We hope that this paper to ensure room construction efficiency is evaluation provide guidance.
\end{abstract}

\section{Introduction}

The implementation of the housing assignmentcurrency policy after that, along with the rapid development of real estate industry, people with the appearance of new housing problem, the price of the house had higher causes of housing shortage situation caused the party and the government's high attention. In order to alleviate the residents' housing's pressure, the central government puts forward security room construction thoughts and real estate development direction.

" Twelfth Five Year Plan" period, the central government has formulated the corresponding state policies and laws and regulations, and put it in 2011, the local government to build 10 million sets of security housing task. From the current research situation, affordable housing research include: supply, distribution two aspects. Chinese scholars despite of the two aspects have research, however, in the indemnificatory housing construction efficiency in domestic are rarely discussed. Security room construction efficiency problem is for the people as soon as possible can equal reform development achievement, further narrow the gap between rich and poor, effective ease social contradictions of the key factors. This paper will use data envelopment analysis (dea) to ensure room in building efficiency on certain exploration.

\section{Affordable housing construction efficiency evaluation index}

In the current policy and economic environment, influence of affordable housing construction efficiency indicators are many, such as the policy factors, basic economic factors on the impact, but from the data selection, we easily available and also the most direct impact indicators into:

Input indicators: government investment funds ( government in low-income housing construction to raise funds, unit) for million; social financing amount (via social financing channels to raise funds for low-income housing construction ), unit for the million yuan; construction land ( have been 
identified for security housing construction project land scale ), unit for mu; these indicators represent the low-income housing construction process of capital, land and other key resources input;

Output indicators: affordable housing construction volume (the volume of work, statistical data to complete the formalities have been started in low-income housing projects completed ), unit is set; affordable housing completion ( referred to as completed, by displaying the current data has been completed to low-income housing projects completed ), unit is set; these indicators represent the low-income housing construction to carry out specific implementation.

\section{Affordable housing construction efficiency evaluation method selection}

The study of input output model, we mainly apply data envelopment analysis. Data envelopment analysis ( Data Envelopment Analysis, referred to as DEA ) is a famous strategist of A.Charnes and W.W.Copper and other scholars to " efficiency " concept as the basis, according to the input and output indicators indicators for the same type of unit relative validity or effectiveness evaluation of a new method of system analysis ${ }^{[1]}$. This method is often used in the production life of the input output system to make management decision and benefit, efficiency evaluation, has become a management science and system engineering is widely used as an effective analysis tool [2]

DEA uses mathematical programming methods, to assess a group with multiple input and multiple output " unit " ( referred to as the decision making unit, Decision Making Unit, DMU DMU, in Hebei province for the administrative city) performance and relative efficiency based on ${ }^{[3]}$, through the DMU collection analysis and comparison, the DMU observation whether the DEA effectively, to determine the " efficient production frontier ", and points out that the invalid DEA, guiding the improvement direction and degree.

\section{Based on the sample data of affordable housing construction efficiency evaluation}

\subsection{Samples and data selection}

This article take the Hebei province each administrative city in 2012 January $\sim 8$ months low-income housing construction schedule data as the research object, the main sources of data in Hebei Province, housing and Urban-Rural Construction Department official website ( http://www.hebjs.gov.cn/hbzfbz/ ). Some data through the Excel software that, model establishment and analysis of the use of DEAP software implementation.

\subsection{Affordable housing construction efficiency evaluation process}

Using DEAP software to establish the model of DEA process is as follows:

4.2.1 and 4.2.2

\subsubsection{DEA input model of input and output index}

As shown in table 1. 
Table 1 DEA model of input and output index system table

\begin{tabular}{|c|c|c|c|c|c|c|c|c|c|c|c|}
\hline & $\begin{array}{l}\text { Shi jia } \\
\text { zhuang }\end{array}$ & $\begin{array}{l}\text { Cheng } \\
\text { de }\end{array}$ & $\begin{array}{l}\text { Zhang } \\
\text { jia kou }\end{array}$ & $\begin{array}{l}\text { Qin } \\
\text { huang } \\
\text { dao }\end{array}$ & $\begin{array}{l}\text { Tang } \\
\text { sha }\end{array}$ & $\begin{array}{l}\text { Lang } \\
\text { fang }\end{array}$ & $\begin{array}{l}\text { Bao } \\
\text { ding }\end{array}$ & $\begin{array}{l}\text { Cang } \\
\text { zhou }\end{array}$ & $\begin{array}{r}\text { Heng } \\
\text { shui }\end{array}$ & $\begin{array}{l}\text { Xing } \\
\text { tai }\end{array}$ & $\begin{array}{l}\text { Han } \\
\text { dan }\end{array}$ \\
\hline $\begin{array}{l}\text { Start volume, } \\
\text { set }\end{array}$ & 15048 & 4026 & 19252 & 4471 & 26647 & 9923 & 15908 & 24838 & 4244 & 19589 & 32392 \\
\hline $\begin{array}{l}\text { Complete } \\
\text { volume, set }\end{array}$ & 10228 & 4812 & 12727 & 6340 & 27577 & 7076 & 9947 & 11351 & 4096 & 8736 & 12979 \\
\hline $\begin{array}{l}\text { Government } \\
\text { investment, } \\
\text { million }\end{array}$ & 146489 & 68620 & 83933 & 54273 & 396901 & 144948 & 152382 & 142694 & 65452 & 120331 & 220843 \\
\hline $\begin{array}{l}\text { Social } \\
\text { financing } \\
\text { amount, } \\
\text { million }\end{array}$ & 38.4 & 0 & 0 & 17 & 34.5 & 15 & 3.3 & 15 & 0 & 14 & 38 \\
\hline $\begin{array}{l}\text { Construction } \\
\text { land, } \mathrm{Mu}\end{array}$ & 2409 & 1001 & 1594 & 715 & 3269 & 1179 & 1805 & 3267 & 881 & 1607 & 2801 \\
\hline
\end{tabular}

\subsubsection{The results' analysis}

The use of DEA software, and used to output index oriented analysis method, in the input indicators remain unchanged, in Hebei Province on the administration of city low-income housing construction starts and the completion of the following analysis, analysis results are shown in the following table.

Table 2 Analytical results of CCR model efficiency

EFFICIENCY SUMMARY:

\begin{tabular}{|l|l|l|l|l|}
\hline & firm & crste & vrste & scale \\
\hline 1 & 1.000 & 0.509 & 1.966 & - \\
\hline 2 & 0.509 & 0.174 & 2.915 & - \\
\hline 3 & 0.174 & 0.647 & 0.270 & drs \\
\hline 4 & 0.647 & 0.230 & 2.814 & - \\
\hline 5 & 0.230 & 1.000 & 0.230 & drs \\
\hline 6 & 1.000 & 0.339 & 2.951 & - \\
\hline 7 & 0.339 & 0.529 & 0.641 & drs \\
\hline 8 & 0.529 & 0.781 & 0.676 & drs \\
\hline 9 & 0.781 & 0.156 & 5.004 & - \\
\hline 10 & 0.156 & 0.614 & 0.254 & drs \\
\hline 11 & 0.614 & 1.000 & 0.614 & drs \\
\hline mean & 0.544 & 0.544 & 1.667 & \\
\hline
\end{tabular}

Note: crste $=$ technical efficiency from CRS DEA

vrste $=$ technical efficiency from VRS DEA

scale $=$ scale efficiency $=$ crste $/$ vrste 
The efficiency analysis of results, without taking into consideration the returns to scale when technical efficiency ( efficiency) is relatively effective to the city of Shijiazhuang, Langfang two city; in considering scale income ( technical efficiency pure technical efficiency ) is relatively effective to the city of Tangshan, Handan two city. This shows, four City in low-income housing construction progress, basic in efficient production frontier, relative to other city high efficiency, good progress of the project.

In addition, Tangshan, Langfang, Zhangjiakou, Baoding, Xingtai, Handan returns to scale is decreasing, it said, in 2012 January $\sim 8$ months during the construction of low-income housing has gradually slowed down or even reverse the situation, the city needs the relevant government departments to raise vigilance, to identify the key issues and proposed solutions.

Table 3 CCR model output indicators slack variable analysis results

\section{SUMMARY OF OUTPUT SLACKS:}

\begin{tabular}{|l|l|l|}
\hline firm output & 1 & 2 \\
\hline 1 & 0.000 & 0.000 \\
\hline 2 & 3574.473 & 0.000 \\
\hline 3 & 0.000 & 0.000 \\
\hline 4 & 7199.560 & 0.000 \\
\hline 5 & 0.000 & 0.000 \\
\hline 6 & 0.000 & 0.000 \\
\hline 7 & 0.000 & 0.000 \\
\hline 8 & 0.000 & 0.000 \\
\hline 9 & 0.000 & 0.000 \\
\hline 10 & 0.000 & 0.000 \\
\hline 11 & 0.000 & 0.000 \\
\hline
\end{tabular}

Through to the output index of the slack variable analysis, Hebei province overall low-income housing starts not just as one wishes, among them Chengde, Qinhuangdao two cities that is most evident, as DMU is invalid, and in low-income housing, devoted inadequacy is closely related to, among them, Chengde City Hall raise money amount is 686200000 yuan, Qinhuangdao city the government to raise funds 542730000 yuan, respectively, in the cities of Hebei province with the index of the bottom second and reciprocal the first.

Thus, two city should increase government support construction investment, broaden sources of income and reduce expenditure, ensure capital adequacy. In addition, the two also needs to increase the working efficiency of low-income housing attention and supervision, so that timely initiation of low-income housing projects and complete the tasks throughout the year. 
Table 4 CCR model unit target value analysis results

\section{SUMMARY OF OUTPUT TARGETS:}

\begin{tabular}{|l|l|l|}
\hline firm output & 1 & 2 \\
\hline 1 & 29585.897 & 20109.287 \\
\hline 2 & 26647.000 & 27577.000 \\
\hline 3 & 29757.915 & 19672.189 \\
\hline 4 & 26647.000 & 27577.000 \\
\hline 5 & 26647.000 & 27577.000 \\
\hline 6 & 29282.234 & 20880.892 \\
\hline 7 & 30094.296 & 18817.448 \\
\hline 8 & 31783.530 & 14525.117 \\
\hline 9 & 27177.288 & 26229.541 \\
\hline 10 & 31900.970 & 14226.703 \\
\hline 11 & 32392.000 & 12979.000 \\
\hline
\end{tabular}

Based on the unit target value analysis, Tangshan, Handan city for the two DEA relatively effective, its target value in the efficient frontier, 11 in Hebei Province Administration, performance is relatively good, and other administrative city of Hebei province are poor performance. In land, capital and other resources quantity invariable situation, Chengde City low-income housing starts, the completion of all differs very much, and effective production frontier considerably, indicating Chengde on low-income housing construction efficiency situation holds enough, need to strengthen the construction of low-income housing project efficiency supervision, to ensure the smooth progress of projects and acceptance.

\section{Summary}

This paper uses DEA model in Hebei Province on the administration of city low-income housing construction efficiency is evaluated and analyzed, found that each city low-income housing construction efficiency is not all, uneven. Through specific discuss various administrative city in relation to the other administrative city in low-income housing and construction work have due effect, reach Tangshan, Handan two administrative city in low-income housing construction efficiency in the province's leading position, and the city of Chengde in low-income housing construction efficiency control of efficiency to be greatly improved, the corresponding Chengde City, city hall on the engineering efficiency should strengthen efficiency supervision, ensure annual low-income housing construction task is finished smoothly.

In addition, we found increased affordable housing construction efficiency is the key is to increase capital investment and the land supply, only in the elements of the input increase strength to ensure efficiency, which will force the local government benefit, and the real estate market caused certain impact, this is we need to further explore the issue.

\section{Reference:}

[1]Chmes A,Cooper WW,Phodes EM.Easuring the Efficiency of DMU[J].European Jounrnal of Operational Research,1978,11(6):429-44

[2] Zhang Yuping DEA based Dalian City Human Settlements sustainable development capacity evaluation [D]. Liaoning: Dissertation of master degree of Liaoning Normal University, 2007:26 30 (In Chinese)

[3] Zhu Yanke, Yang Huiyao. Guangdong saves each city economy to develop the relative efficiency of DEA [J]. southern economy, 2002, 11 ( 3), 42 - 43(In Chinese) 